\title{
PENGEMBANGAN LEMBAR KERJA MAHASISWA BERBASIS MASALAH DAN PROYEK PADA MATAKULIAH ANALISIS DATA
}

\author{
Jackson Pasini Mairing (jacksonmairing@yahoo.co.id) \\ Dadang Lorida \\ Prodi Pendidikan Matematika FKIP Universitas Palangka Raya
}

\begin{abstract}
ABSTRAK
Mahasiswa dapat memiliki kemampuan menganalisis data jika mahasiswa berlatih menyelesaikan masalah dan proyek yang berkaitan dengan cara menganalisis dan menarik kesimpulan dari data penelitian. Tujuan penelitian ini adalah mengembangkan Lembar Kerja Mahasiswa. Analisis Data berbasis masalah dan proyek yang dapat membantu mahasiswa memiliki kemampuan dalam menganalisis data penelitian. Pengembangan Lembar Kerja Mahasiswa ini menggunakan tahap-tahap Plomp. Subjek penelitiannya adalah 24 mahasiswa Pendidikan Matematika Fakultas Keguruan dan IImu Pendidikan Universitas Palangka Raya. Hasil implementasi menunjukkan bahwa penggunaan Lembar Kerja Mahasiswa dapat mendorong mahasiswa untuk: memiliki pengetahuan bermakna, (b) menyenangi matakuliah Analisis Data dan metode belajar yang digunakannya, termotivasi untuk belajar dan menyelesaikan masalah dan proyek dalam Lembar Kerja Mahasiswa secara mandiri, aktif selama perkuliahan, dan memiliki kemampuan dalam menganalisis data menggunakan Minitab dan Microsoft Excel.
\end{abstract}

Kata kunci: analisis data, lembar kerja mahasiswa, masalah, pemecahan masalah, proyek

\begin{abstract}
Students have ability to analyze data if they practiced to solved problems/projects that are related to analyzed and made conclusion from research data. The aim of this research was to develop the student's worksheets of data analysis based on the problems and projects that can help students to have ability analysis research data. The development of the student's worksheets used Plomp's stages. Results of student's workshets implementation showed that those can help: students to have meaningful understanding, like the analysis data lecture, have motivated individually to learned concepts of data analysis and solved the problems and projects in student's worksheets, actived in learning process, and had ability to analyzed data by Minitab and Microsoft Excel.
\end{abstract}

Keywords: data analyze, problem solving, problems, projects, student's worksheets

Matakuliah Analisis Data adalah salah satu matakuliah pada Program Studi Pendidikan Matematika FKIP Universitas Palangka Raya yang bertujuan agar mahasiswa memiliki kemampuan dalam menganalisis data suatu penelitian. Prasyarat matakuliah ini adalah Statistika Dasar. Beberapa materi dalam Analisis Data juga dipelajari pada Statistika Dasar seperti uji normalitas, uji homogenitas, dan uji-t. Perbedaannya pada Analisis Data tidak mulai dengan pengertian statitika dan jenis-jenis data, tetapi langsung pada eksplorasi data dan uji-uji Statistika yang berguna bagi mahasiswa dalam menganalisis data penelitian. 
Kemampuan menganalisis data penting bagi mahasiswa yang tugas akhir/skripsinya menggunakan analisis data kuantitatif. Mahasiswa yang memiliki kemampuan tersebut akan lebih cepat menyelesaikan studinya. Akan tetapi, pengalaman peneliti sebagai dosen pengampu matakuliah Analisis Data dan penguji proposal/skripsi mahasiswa menunjukkan bahwa mahasiswa dapat mencari statistik hitung tertentu seperti t-hitung atau F-hitung, tetapi belum memiliki pengetahuan bermakna mengenai uji-uji tersebut. Selain itu, mahasiswa belum dapat menjelaskan kerangka berpikir dalam membuat suatu hipotesis penelitian. Mengapa suatu penelitian menggunakan hipotesis dua arah bukan satu arah? Mahasiswa akan mampu menjawab pertanyaanpertanyaan tersebut jika ia memiliki pengetahuan yang bermakna.

Pengetahuan akan bermakna apabila pengetahuan tersebut dihubungkan dengan pengetahuan-pengetahuan lainnya atau dihubungkan dengan kejadian dalam kehidupan sehari-hari. Pengetahuan yang kaya akan hubungan ini disebut dengan pengetahuan konseptual (Hudojo, 2005: 164). Menurut pandangan konstruktivime, pengetahuan inilah yang seharusnya pertama kali dimiliki mahasiswa dalam belajar (Krulik, at al.: 2003: 7). Selanjutnya, mahasiswa mengembangkan pengetahuan proseduralnya.

Salah satu metode pembelajaran yang dapat membantu mahasiswa dalam menghubungkan apa yang dipelajari dengan kehidupan sehari-hari dan dalam memiliki pemahaman konseptual adalah pembelajaran berbasis masalah (PBM) dan pembelajaran berbasis proyek (PBP). PBM adalah suatu metode pembelajaran yang dimulai dengan pemberian masalah matematika (Sutawidjaja \& Afgani, 2011: 7.2). Masalah matematika adalah suatu kondisi yang membutuhkan penyelesaian dimana jalan/cara untuk menyelesaikannya tidak dapat dilihat secara langsung (Polya, 1973, 1981; Krulik, at al, 2003; Shumway, 1980; Sakshaug \& Olson, 2002).

Penggunaan masalah dalam pembelajaran memiliki beberapa keunggulan yaitu masalah berkaitan dengan kejadian dalam kehidupan sehari-hari sehingga mahasiswa dapat mengetahui manfaat langsung dari materi/konsep yang dipelajarinya dalam kelas. Masalah juga memberi kesempatan kepada mahasiswa untuk berpikir kritis dan kreatif dan menggunakan idenya sendiri dalam memecahkan masalah (Bush \& Greer, 1999: 18). Kedua cara berpikir tersebut tergolong kemampuan berpikir tingkat tinggi yang bermanfaat dalam belajar dan dalam kehidupan sehari-hari.

Pembelajaran berbasis proyek adalah pembelajaran yang dimulai dengan pengajuan proyek kepada mahasiswa. Selanjutnya, mahasiswa diberikan kesempatan 1 sampai 4 minggu untuk menyelesaikan proyek tersebut secara berkelompok. Penyelesaian proyek tersebut dipresentasikan mahasiswa secara berkelompok di depan kelas. Proyek merupakan masalah matematika yang membutuhkan waktu yang cukup lama untuk menyelesaikannya (Bush \& Greer, 1999: 18).

Penggunaan proyek dalam perkuliahan memiliki beberapa keunggulan antara lain memberi kesempatan kepada mahasiswa untuk menghubungkan statistika dengan kehidupan sehari-hari. Proyek juga dapat memotivasi mahasiswa dalam belajar secara mandiri. Penggunaan proyek memberi kesempatan kepada mahasiswa untuk mendemonstrasikan kemampuannya dalam mengkomunikasikan ide-ide matematika baik secara tulisan maupun lisan (Bush \& Greer, 1999: 18).

Masalah dan proyek dapat dituangkan dalam suatu Lembar Kerja Mahasiswa (LKM). Penggunaan LKM ini dapat mendorong mahasiswa untuk terlibat aktif dalam kegiatan kuliah. Akan tetapi saat ini belum ada LKM untuk matakuliah Analisis Data. Hal tersebut mendorong peneliti untuk mengembangkan LKM berbasis masalah dan proyek dalam matakuliah Analisis Data yang penggunaannya dapat mendorong mahasiswa Pendidikan Matematika FKIP Universitas Palangka Raya memiliki kemampuan dalam menganalisis suatu data penelitian kuantitatif. 


\section{METODE}

Subjek penelitian adalah mahasiswa Pendidikan Matematika Universitas Palangka Raya yang mengambil matakuliah Analisis Data tahun ajaran 2013/2014 yang berjumlah 24 orang. Beberapa mahasiswa berasal dari kabupaten-kabupaten yang jaraknya jauh dari ibu kota Provinsi dan belum memiliki sarana Teknologi Informasi yang memadai. Ada mahasiswa yang mengambil matakuliah ini baru mengenal dan belajar komputer pada waktu kuliah.

Matakuliah Analisis Data dapat diambil mahasiswa yang pernah menempuh Statistika Dasar. Matakuliah Statistika Dasar dapat diambil oleh mahasiswa di semester 3. Waktu penelitian adalah Juli sampai dengan Desember 2013. Tempat penelitian ruang kuliah D Pendidikan Matematika. Pengembangan LKM ini menggunakan tahap Plomp (1997: 2-3) yaitu tahap (1) investigasi awal, (2) desain, (3) realisasi/konstruksi, (4) tes, evaluasi \& revisi, dan (5) implementasi. Secara umum, prosedur pengembangannya dapat dilihat pada Gambar 1.

\section{HASIL DAN PEMBAHASAN}

Hasil penelitian pada Tahap Investasi Awal menunjukkan bahwa kendala-kendala yang dihadapi oleh mahasiswa dalam mempelajari materi-materi dalam Analisis Data adalah metodemetode statistika dipelajari mahasiswa secara prosedural tanpa makna. Mahasiswa hanya menghapal rumus-rumus statistika beserta tahap-tahap melakukan uji statistik tertentu. Perkuliahan yang penuh rumus dan prosedur akan membuat mahasiswa merasa jemu dan tidak termotivasi dalam belajar. Maka dikembangkanlah LKM berbasis masalah dan proyek untuk mengatasi hal tersebut.

Tahap Desain, peneliti menyusun urutan materi, metode-metode statistika dalam LKM, dan tahap-tahap belajar yang akan digunakan. Materi-materi tersebut adalah (a) Eksplorasi Data (LKM 1), (b) Ukuran Pemusatan (LKM 2), (c) Ukuran Penyebaran (LKM 3) (d) Perbandingan Dua Sampel (LKM 4), (e) Korelasi(LKM 5), (f) Regresi (LKM 6), dan (g) Analisis Ragam Satu Arah(LKM 7) .

Pada tahap Realisasi/Konstruksi, peneliti merealisasi Draft I LKM Analisis Data dan instrumen-instrumen yang digunakan dalam penelitian yaitu lembar penilaian ahli, tes, angket mahasiswa, dan lembar pengamatan aktivitas mahasiswa.

Tahap Tes, Evaluasi, dan Revisi, draf I LKM tersebut dievaluasi oleh 2 ahli yaitu ahli bidang pengembangan produk pendidikan dan ahli di bidang statistika. Hasilnya adalah kedua ahli menyatakan bahwa Draft I LKM layak digunakan dalam matakuliah Analisis Data.

Tahap Implementasi dilakukan sebanyak 14 kali pertemuan mulai tanggal 19 September 2013. Kuliah Analisis Data dilakukan setiap Kamis jam 07.00-09.30 (3 sks) di Ruang D Workshop Pendidikan Matematika. Pada pertemuan pertama, peneliti menyampaikan bahwa beberapa mahasiswa membutuhkan waktu yang lama dalam menyelesaikan skripsinya karena kesulitan dalam menganlisis data. Kesulitan ini dapat diatasi jika mahasiswa memanfaatkan perangkat lunak tertentu seperti Minitab dan MS Excel dalam mengeksplorasi dan menganalisis data. Peneliti mendemonstrasikan cara menganalisis data real hasil penelitian mahasiswa menggunakan Minitab dan menceritakan hasil eksplorasi dan analisisnya dalam waktu 15 menit. Peneliti menyatakan bahwa pada matakuliah ini, mahasiswa mampu menganalisis data dengan Minitab dan Microsoft Excel. Tujuan penggunaan Excel agar mahasiswa dapat mengetahui prosedur hitung manual dalam menghasilkan statistik uji tertentu. Kegiatan tersebut dilakukan peneliti untuk memotivasi mahasiswa agar mempelajari modul/buku statistika dan menyelesaikan proyek/masalah dalam LKM secara mandiri. 


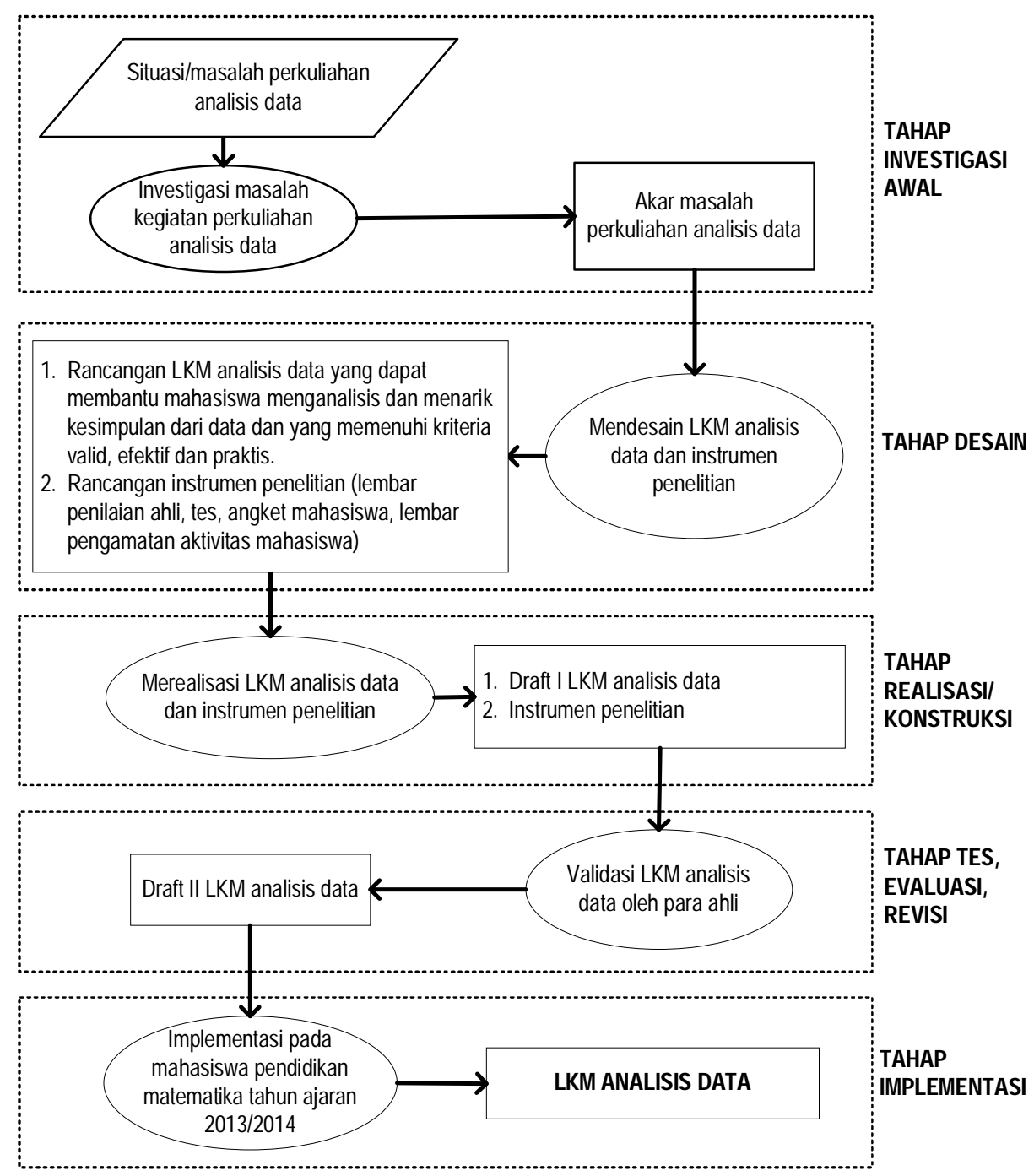

Gambar 1. Tahap-tahap penelitian pengembangan LKM analisis data

Peneliti menjelaskan secara singkat mengenai Minitab dan mendemonstrasikannya di depan kelas. Mahasiswa mengikuti apa yang dilakukan peneliti. Selanjutnya, peneliti menjelaskan masalah dan proyek yang harus diselesaikan mahasiswa secara berkelompok setiap minggunya.

Penyelesaian masalah dan proyek tersebut dipresentasikan mahasiswa pada pertemuan minggu berikutnya. Perkuliahan pertama diakhiri dengan pembagian kelompok. Satu kelompok terdiri atas 45 mahasiswa. 


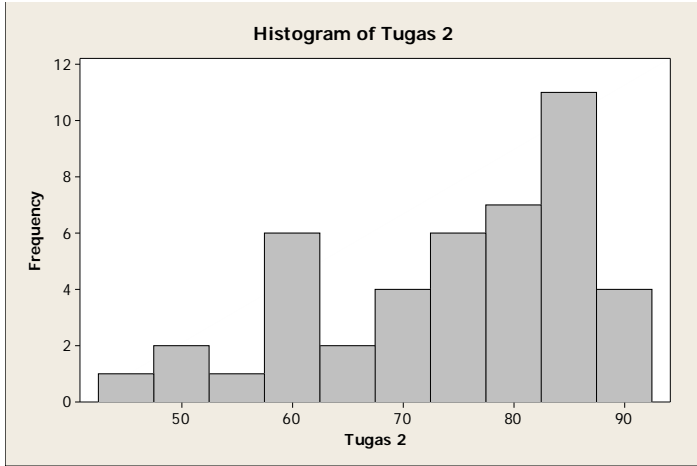

Kelompok 1

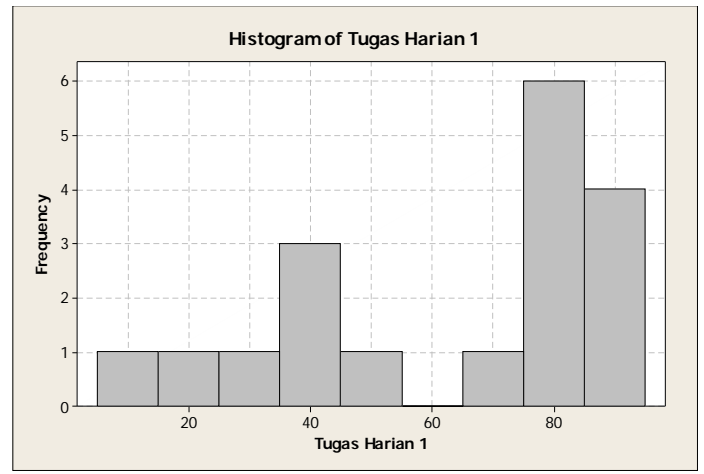

Kelompok 3

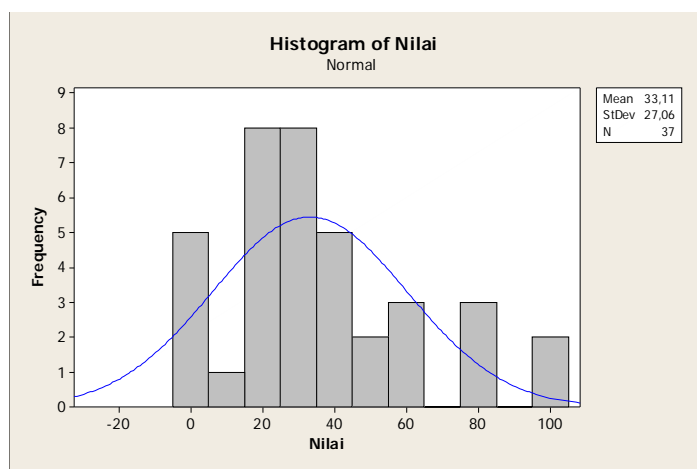

Kelompok 2

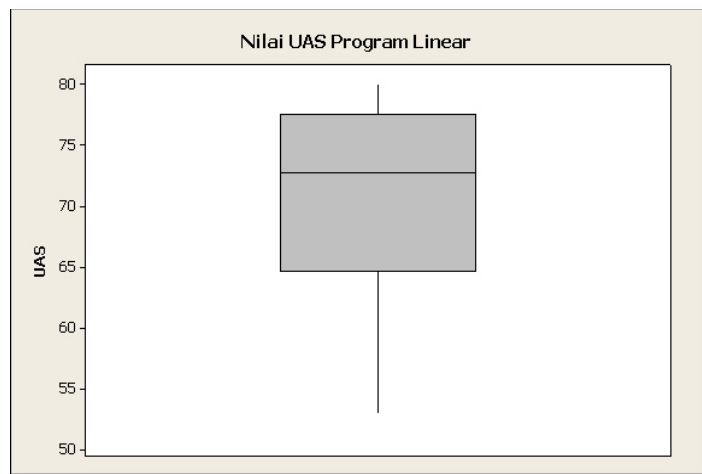

Kelompok 4

Gambar 2. Hasil Kerja Kelompok Pada Pertemuan 1

Petemuan 2 dan 3 menggunakan LKM 1. Pertemuan ini diawali dengan diskusi mengenai kegunaan eksplorasi data dalam memahami karakteristik data hasil penelitian. Selanjutnya, satu per satu kelompok mempresentasikan hasil kerjanya menggunakan LCD. Contoh hasil kerja mahasiswa dalam mengeksplorasi data ditunjukkan pada Gambar 2. Tampak bahwa semua kelompok dapat menggunakan Minitab untuk mengeksplorasi data. Kemampuan tersebut dipelajari mahasiswa secara mandiri memanfaatkan Petunjuk Minitab yang terdapat dalam LKM. Bukan hanya itu, kelompok 3 dapat membuat grid (garis putus-putus) pada histogramnya, padahal tidak ada petunjuk Minitab dalam LKM mengenai hal tersebut. Ketika diminta mahasiswa lainnya untuk mengulangi membuat grid di depan kelas, salah sorang mahasiswa (RB) menjawab "sangat bisa". Ini menunjukkan bahwa RB telah mengetahui cara membuat grid sebelumnya. Kemampuan ini diperoleh dari kegiatannya mencoba-coba sendiri fasilitas yang terdapat pada Minitab.

Pertemuan 4-5 menggunakan LKM 2 dan 3. Perkuliahan diawali dengan pertanyaan peneliti mengenai makna dari rata-rata, median, dan modus sebagai ukuran pemusatan? Peneliti juga mengungkapkan kekeliruan yang sering dilakukan mahasiswa yaitu ketiga statistik tersebut digunakan sekaligus untuk menggambarkan satu variabel tertentu seperti hasil belajar. Padahal ketiganya menunjukkan hal yang sama yaitu ukuran pemusatan. Mahasiswa seharusnya memilih satu dari ketiga statistik yang paling sesuai untuk menggambarkan hasil belajar. 
Mahasiswa secara bergiliran menyajikan hasil kerjanya secara berkelompok di depan kelas. Kelompok 1 dan 2 mempresentasikan LKM 2 (ukuran pemusatan), sedangkan kelompok 3 dan 4 menyajikan LKM 3 (ukuran penyebaran). Kegiatan dilanjutkan dengan diskusi kelas dimana mahasiswa melakukan refleksi untuk memahami makna dari ukuran pemusatan dan penyebaran.

Pertemuan 6-9 menggunakan LKM 4. Perkuliahan dimulai dengan diskusi mengenai contohcontoh penelitian yang menggunakan uji-t sebagai alat analisisnya. Selanjutnya masing-masing kelompok menyajikan hasil kerjanya di depan kelas secara bergiliran. Kelompok 2 yang pertama kali menyajikan hasil kerjanya. Pertama, mahasiswa menyampaikan ringkasan data penelitian yang diambil dari skripsi mahasiswa beserta hipotesisnya. Berikutnya mahasiswa mempresentasikan bagaimana melakukan uji kenormalan menggunakan khi-kuadrat. Kelompok tersebut dapat menggunakan uji khi-kuadrat dan uji Kolmogorov-Smirnov menggunakan Excel. Padahal peneliti hanya memberikan buku mengenai uji tersebut, tetapi tidak menjelaskannya. Kemampuan menggunakan Excel menunjukkan bahwa mahasiswa memahami prosedur hitung manual. Bukan hanya itu, kelompok ini dapat menggunakan Excel untuk uji-F (homogenitas varians), uji-t (perbandingan dua sampel parametrik), dan uji Mann-Whitney (perbandingan dua sampel non parametrik). Semua kemampuan tersebut dipelajari mahasiswa sendiri secara berkelompok. Peneliti meminta mahasiswa memberikan tepuk tangan kepada kelompok ini. Tiga kelompok lainnya juga dapat menggunakan uji-uji tersebut dalam menganalisis data hasil penelitian mahasiswa sebelumnya.

Penggunaan Uji Non parametrik Mann-Whitney ini tidak direncanakan sebelumnya oleh peneliti. Ini terjadi karena ada mahasiswa yang bertanya bagaimana membandingkan dua sampel jika datanya tidak normal. Peneliti menyatakan bahwa ada uji untuk hal tersebut yaitu Uji MannWhitney. Uji ini dapat dilakukan di Minitab. Selanjutnya, peneliti memberikan buku kepada mahasiswa dan memberi tantangan untuk dapat menggunakan uji ini menggunakan Excel.

Pada pertemuan kesepuluh, peneliti mengundang salah seorang mahasiswa yang memiliki data hasil penelitian yang belum dianalisis. Peneliti memberi tugas kepada mahasiswa untuk menganalisis data tersebut mulai dari mengeksplorasi data, membuat tabel frekuensi (menghitung banyak kelas, panjang kelas, interval kelas dan menghitung frekuensi untuk masing-masing kelas), menguji kenormalan menggunakan uji khi-kuadrat, menguji homogenitas menggunakan uji-F dan melakukan uji-t menggunakan Excel. Tugas ini dimaksudkan untuk mengetahui kemampuan setiap mahasiswa dalam menganalisis data menggunakan Minitab dan Excel. Ternyata ada tiga mahasiswa yang mampu menganalisis data tersebut dalam waktu 1 jam. Peneliti meminta mahasiswa lainnya untuk menyelesaikan analisis ini secara individual di rumah dan mengirim hasil analisisnya melalui email. Hasilnya adalah semua mahasiswa dapat menganalisis data tersebut.

Pertemuan 11-12 menggunakan LKM 5 dan 6 mengenai korelasi dan regresi. Pada pertemuan 11, mahasiswa mengalami kesulitan pada waktu mencari persamaan regresi dan tabel analisis ragamnya menggunakan Excel. Peneliti meminta mahasiswa untuk mempelajarinya kembali secara mandiri melalui tulisan peneliti yang dapat diunduh di blog dengan alamat:

jacksonmairing.wordpress.com. Pada pertemuan berikutnya, mahasiswa telah dapat menganlisisnya menggunakan Excel. Mahasiswa juga dapat menghasilkan persamaan regresi langsung dari Excel.

Pertemuan 13-14 seharusnya mahasiswa membahas LKM terakhir. Akan tetapi pertemuan ini diisi dengan diskusi mengenai penelitian kualitatif. Ini karena mahasiswa meminta peneliti untuk berdiskusi mengenai penelitian kualitatif mengingat beberapa penelitian mahasiswa yang berkembang saat ini menggunakan pendekatan ini. 
Perkuliahan diakhiri dengan pemberian tes (3 pertanyaan) dan angket kepada mahasiswa. Pertanyaan pertama dan kedua pada tes berkaitan dengan pemahaman mahasiswa mengenai ukuran pemusatan dan penyebaran. Pertanyaan ketiga berkaitan dengan kemampuan mahasiswa menganalisis data penelitian menggunakan uji-t. Pada pertanyaan pertama dan kedua, ada 83\% mahasiswa yang menjawab benar. Jawaban yang benar menunjukkan mahasiswa telah memiliki pengetahuan yang bermakna mengenai kedua ukuran tersebut. Pada pertanyaan ketiga, rata-rata nilai mahasiswa sebesar 89 (skala 0-100). Secara umum, rata-rata nilai mahasiswa adalah 89. Ini berarti pemahaman dan kemampuan mahasiswa dalam menganalisis data tergolong tinggi. Berikut jawaban mahasiswa MI pada pertanyaan 1 dan 2.

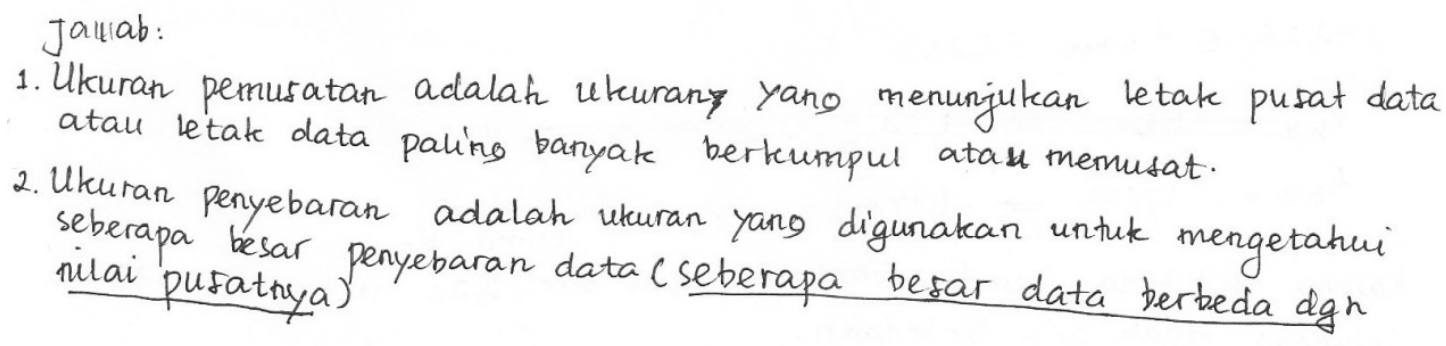

Gambar 2. Jawaban MI pada pertanyaan 1 dan 2

Hasil pengamatan oleh dua orang observer menunjukkan bahwa 71\% mahasiswa aktif pada waktu perkuliahan. Aktif disini ditunjukkan dengan mahasiswa bertanya, mengajukan pendapat/jawaban atau menganalisis data menggunakan Excel/Minitab dalam kelas. Keaktifan ini sejalan dengan aktivitas mahasiswa selama kegiatan presentasi kelas dimana mahasiswa secara mandiri termotivasi untuk menyelesaikan masalah dan proyek dalam LKM dan mempelajari sendiri materi-materi yang relevan.

Hasil pengolahan angket disusun dalam Tabel 1.

Tabel 1. Hasil Pengolahan Angket Mahasiswa terhadap Model Belajar dalam Matakuliah Analisis Data

\begin{tabular}{|c|c|c|c|c|}
\hline \multirow[t]{2}{*}{ Pertanyaan } & \multicolumn{4}{|c|}{ Persentase } \\
\hline & STS & TS & $\mathbf{S}$ & SS \\
\hline Apakah Anda saat ini menyenangi matakuliah Analisis Data? & 0 & 0 & 62 & 38 \\
\hline $\begin{array}{l}\text { Apakah Anda merasa senang dengan metode belajar yang } \\
\text { digunakan pada matakuliah ini? }\end{array}$ & 0 & 5 & 90 & 5 \\
\hline Apakah Anda memahami materi-materi dalam matakuliah ini? & 0 & 10 & 81 & 10 \\
\hline $\begin{array}{l}\text { Apakah Anda merasa termotivasi untuk mempelajari materi- } \\
\text { materi secara mandiri pada matakuliah ini? }\end{array}$ & 0 & 10 & 33 & 57 \\
\hline $\begin{array}{l}\text { Apakah Anda telah memiliki kemampuan menganalisis data } \\
\text { setelah menempuh matakuliah ini? }\end{array}$ & 0 & 14 & 81 & 5 \\
\hline $\begin{array}{l}\text { Apakah Anda terdorong untuk menyelesaikan soal-soal secara } \\
\text { mandiri pada matakuliah ini? }\end{array}$ & 0 & 19 & 62 & 19 \\
\hline $\begin{array}{l}\text { Apakah Anda mengharapkan matakuliah lainnya menggunakan } \\
\text { metode yang sama dengan matakuliah Analisis Data? }\end{array}$ & 0 & 29 & 48 & 24 \\
\hline
\end{tabular}


Hasil pengolahan angket tersebut menunjukkan bahwa setidaknya terdapat $90 \%$ mahasiswa yang menyenangi matakuliah ini dan metode yang digunakan dalam kelas. Perasaan senang ini mendorong setidaknya terdapat $80 \%$ mahasiswa termotivasi untuk mempelajari materi-materi dalam LKM dan menyelesaikan masalah/proyek secara mandiri dalam kelompoknya masing-masing.

Penggunaan LKM berbasis masalah dan proyek yang diintegrasikan dengan Minitab dan Excel dapat mendorong mahasiswa untuk memiliki pengetahuan yang bermakna dan hasil belajar yang tinggi. Hasil ini sejalan dengan Hmelo-Silver (2004) yang menyatakan bahwa penggunaan masalah dalam pembelajaran dapat membantu siswa mengembangkan pemahaman yang fleksibel dan ketrampilan-ketrampilan belajar. Plogger dan Hecht (2009) juga menyatakan bahwa penggunaan software tertentu dapat meningkatkan pemahaman matematis siswa. Selain itu, penggunaan komputer dan software di sekolah berkorelasi positif dengan pencapaian akademik (Judge, 2005). Siswa-siswa yang belajar dengan lingkungan belajar yang memanfaatkan komputer memiliki pemahaman yang lebih baik dibandingkan siswa yang belajar dengan pengajaran tradisional (Eskrootchi \& Oskrochi, 2010)

Pemahaman yang bermakna terjadi karena mahasiswa memiliki sikap positif terhadap matakuliah ini dan metode yang digunakan. Sembilan puluh persen mahasiswa menyenangi matakuliah ini. Hasil penelitian Choi-Koh (2000), Huang, Liu \& Chang (2012) menyatakan bahwa penggunaan komputer dapat memotivasi siswa dalam belajar dan membuat siswa lebih mampu dalam memecahkan masalah.

\section{KESIMPULAN DAN SARAN}

LKM matakuliah Analisis Data dapat membantu mahasiswa dalam menganalisis dan menarik kesimpulan dari data. Peneliti menggunakan tahap Plomp (1997) untuk mengembangkan LKM tersebut. Hasil implementasi menunjukkan hal-hal sebagai berikut.

Penggunaan LKM berbasis masalah dan proyek dapat mendorong mahasiswa memahami secara bermakna materi-materi dalam matakuliah Analisis Data. Ini ditunjukkan dari hasil angket yang menyatakan 91\% mahasiswa menyatakan setuju atau sangat setuju dengan pernyataan bahwa mahasiswa memahami materi-materi dalam matakuliah ini.

Penggunaan LKM juga mendorong mahasiswa menyelesaikan masalah dan proyek secara mandiri di kelompoknya masing-masing. Hasil angket menyatakan 90\% mahasiswa menyatakan setuju atau sangat setuju mengenai hal ini.

Penggunaan LKM dapat mendorong mahasiswa menyenangi matakuliah Analisis Data dan metode belajar yang digunakannya. Hasil angket menyatakan tidak kurang dari $90 \%$ mahasiswa setuju atau sangat setuju dengan pernyataan tersebut. Hal tersebut tampak dari keaktifan siswa selama perkuliahan. Hasil pengamatan menunjukkan $71 \%$ mahasiswa aktif bertanya atau mengajukan pendapat dan jawaban atau menggunakan Minitab/Excel untuk menganalisis data selama kegiatan perkuliahan. Pertanyaan yang diajukan tidak hanya yang ada di LKM, tetapi beberapa di antaranya di luar LKM seperti uji nonparametrik Mann-Whitney, Uji Kenormalan Kolmogorov-Smirnow atau penelitian kualitatif.

Penggunaan LKM berbasis masalah dan proyek ini dapat mendorong mahasiswa memiliki kemampuan dalam menganalisis data menggunakan Minitab dan Excel. Penggunaan Excel dimaksudkan agar mahasiswa mengetahui prosedur manual, tetapi tidak membuat jemu dengan perhitungannya. Hal ini ditunjukkan dengan semua mahasiswa dapat menyelesaikan tugas yang berkaitan dengan menganalisis data penelitian sebenarnya. Rata-rata hasil tes akhir sebesar 89\% 
mahasiswa yang menunjukkan kemampuan analisis data tergolong tinggi. Hasil angket juga menyatakan bahwa ada 86\% mahasiswa yang menyatakan memiliki kemampuan dalam menganalisis data.

\section{UCAPAN TERIMAKASIH}

Penulis berterimakasih kepada Ketua Program Studi Pendidikan Matematika yang telah mengijinkan dan memfasilitasi untuk dilakukan penelitian ini di kelas matakuliah Analisis Data.

\section{REFERENSI}

Bush, W. S. \& Greer, A. S. (1999). Mathematics assessment: A practical handbook for grades 9-12. Reston: NCTM, Inc.

Choi-Koh, S. S. (2000). A problem solving model of quadratic min values using computer. International Journal of Instructional Media, 27(1), 73-82.

Eskrootchi, R. \& Oskrochi, G. R. (2010). A Study of the efficacy of project based learning integrated with computer-based simulation. STELLA. Educational Technology \& Society, 13(1), 236245.

Hmelo-Silver, C. E. (2004). Problem based learning: What and how do students learn? Educational Psychology Review, 16(3), 235-266.

Huang, T. H., Liu, Y. C. \& Chang, H. C. (2012). Learning achievement in solving word-based mathematical questions through a computer-assisted learning system. Educational Technology \& Society, 15(1), 248-259.

Hudojo, H. (2005). Kapita selekta pembelajaran matematika. Malang: Universitas Negeri Malang.

Judge, S. (2005). The impact of computer technology on academic achievement of young African American children. Journal of Research in Childhood Education, 20(2), 91-101.

Krulik, S., at al. (2003). Teaching mathematics in middle schools. A practical guide. Boston: Pearson Education Inc.

Ploger, D. \& Hecht, S. (2009). Enhancing children's conceptual understanding of mahtematics through chartworld software. Journal of Research in Childhood Education, 25(3), 267-277.

Polya, G. (1973). How to solve It (2nd). New Jersey: Princeton University.

Polya, G. (1981). Mathematical discovery: On understanding, learning and teaching problem solving, Combined Edition. New York: John Willey \& Sons, Inc.

Plomp, T. (1997). Educational \& training systems design. Netherlands: University of Twente.

Sakshaug L., Olson, M. \& Olson, J. (2002). Children are Mathematical Problem Solvers. Reston, VA: NCTM, Inc.

Shumway, R. J. (1980). Research in mathematics education. Reston, VA: NCTM Inc.

Sutawidjaja, A. \& Afgani, J. D. (2011). Pembelajaran matematika. Jakarta: Universitas Terbuka. 